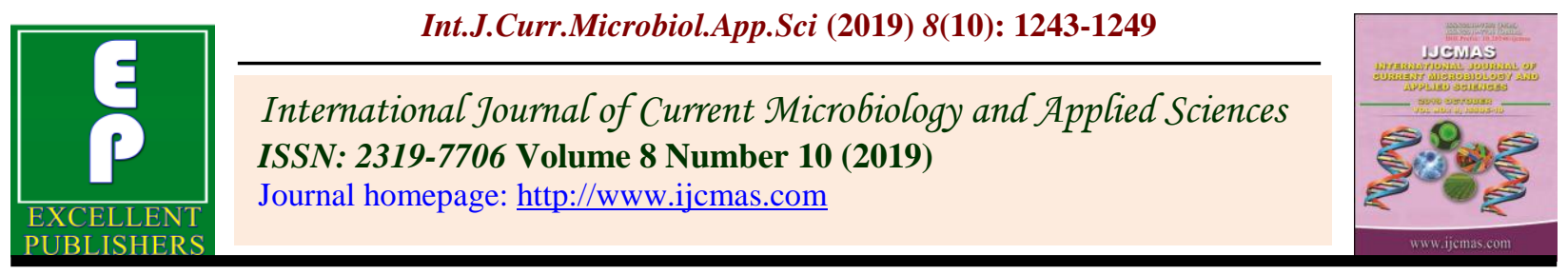

Original Research Article

https://doi.org/10.20546/ijcmas.2019.810.146

\title{
A Comparative Study of Antibiotic Sensitivity Pattern of Escherichia coli Isolated from Various Clinical Samples over a Period of 3 Years
}

\author{
Krunal Shah* \\ PIMSR, Parul University, Waghodia, Vadodara, Gujarat, India \\ *Corresponding author
}

\begin{tabular}{|l|}
\hline K e y w o r d s \\
Nosocomial \\
infection, Blood \\
stream, \\
Bacteriological \\
investigation, \\
Antibiotic \\
\hline Article Info \\
\hline $\begin{array}{l}\text { Accepted: } \\
\text { 10 September } 2019 \\
\text { Available Online: } \\
\text { 10 October } 2019\end{array}$ \\
\hline
\end{tabular}

A B S T R A C T
Escherichia coli, a gram negative bacillus, are present as a normal flora in human intestine. It is present in hospital environment and a common cause of nosocomial infection. In recent years it has shown resistance to various groups of antibiotics. Specimens like Urine, Pus, ET secretion; Sputum, etc were processed in Clinical Microbiology Laboratory for isolation and identification of E. coli. After identification E. coli was processed for Antibiotic Sensitivity testing using Kirby Bauer method. A total of 1237 samples had E. coli isolated. Out of 1237 E. coli isolated $540(43.65 \%)$ were isolated from female patients while $697(56.35 \%)$ were from male patients. Isolation was highest from Urine $(50.69 \%)$ followed by Pus (36.14\%) sample. Over all sensitivity of E. coli was as follow - Imipenam (64.63\%), Amikacin (61.85\%), Gentamicin (52.75\%), Cotrimoxazole (37.90\%), Cefepime (27.03\%), Ciprofloxacin (26.62\%), Cefotaxime (21.50\%), Cefuroxime (12.20\%), Cefoxitin (12.50\%), Amoxicillin (10.54\%), and Ceftazidime (4.57\%). Every hospital needs to prepare antibiogram not only according to organisms but also according to clinical specimens so that empirical therapy can be started before culture and sensitivity investigation.

\section{Introduction}

Escherichia coli, a gram negative bacillus, is present as a normal flora in human intestine. It is present in hospital environment and is a common cause of nosocomial infection. In recent years it has shown resistance to various groups of antibiotics. We are now having very limited numbers of antibiotics which are effective against Escherichia coli. E. coli is ranked as the most common cause of hospital acquired infection in many hospitals (Berkley et al., 2005).

Different E. coli strains were found in high numbers and very frequently among the pathogenic microorganisms isolated from around ten teaching hospitals in China (Wang et al., 2010). One of the leading pathogen causing urinary tract infections is E. coli 
(Wagenlehner et al., 2008; De Francesco et al., 2007; Kashef et al., 2010). E. coli is also among the most common pathogens causing blood stream infections (Biedenbach et al., 2004), wound infection, otitis media and other complications in humans (Gebre-Sellassie et al., 2007; Khan et al., 2002). E. coli has caused many deaths in children below the age of 5 years in developing countries and worldwide as it is one of the common causes of food and water-borne human diarrhea (Turner et al., 2006).

Decreasing rate of antibiotic sensitivity toward E. coli in developed and developing countries is of growing concern (Bell et al., 2002; El Kholy et al., 2003). In general, approximately only $5 \%$ of cases with severe symptoms are treated considering bacteriological investigation while up to $95 \%$ of cases without it (Dromigny et al., 2005). E. coli shows substantial variation in susceptibility profiles according to geographic location and also shows significant differences in various populations and environments (Erb et al., 2007).

Present study is focusing isolation and antibiotic susceptibility pattern of $E$. coli isolated not only from urine but also from various other clinical specimens so that overall profile of antibiotic sensitivity towards $E$. coli can be used for future treatments.

\section{Materials and Methods}

Study was conducted prospectively for 3 years. Specimens like Urine, Pus, ET secretion; Sputum, etc were received in Clinical Microbiology Laboratory from various indoor patients. Specimens were processed for Culture and identification of $E$. coli. Samples were inoculated on MacConkey agar, Blood agar, Nutrient agar and then incubated aerobically at $37^{\circ} \mathrm{C}$ for 24 hours. From positive cultures, $E$. coli were identified according to the standard operational procedures as per the standard microbiological methods (Cheesbourgh, 1991).

After identification E. coli was processed for Antibiotic Sensitivity testing using Kirby Bauer method. Antimicrobial susceptibility tests were done on Mueller-Hinton agar using Kirby Bauer disk diffusion method (Bauer et al., 1996). The antimicrobial agents tested were: Amoxicillin, gentamicin, Amikacin ciprofloxacin, cefuroxime, cefepime, cefotaxime cotrimoxazole, Imipenam, ceftazidime, cefoxitin. Antibiotic Sensitivity data were interpreted according to CLSI guidelines (CLSI, 2017). A reference strain of E. coli ATCC 25922 was used for quality control for antimicrobial susceptibility tests (CLSI, 2017).

\section{Results and Discussion}

Over a period of 3 years total of 1237 samples had E. coli isolated. Out of 1237 E. coli isolated $540(43.65 \%)$ were isolated from female patients while $697(56.35 \%)$ were from male patients. Isolation was highest from Urine $(50.69 \%)$ followed by Pus (36.14\%) sample.

Highest percentage of sensitivity towards $E$. coli was shown by Imipenem (average $64.63 \%$ ) followed by Amikacin (average 61.85). When comparing antibiotic sensitivity among different clinical specimen, Imipenem has highest sensitivity for $E$. coli isolated from Endo tracheal secretion while lowest sensitivity for $E$. coli isolated from catheter tip.

Amikacin has highest sensitivity for Ascitic fluid and lowest sensitivity for Endo tracheal secretion. Lowest percentage of sensitivity towards $E$. coli was shown by ceftazidime followed by amoxicillin. Sensitivity pattern of E. coli for urine was as follow - Imipenam 
(77.90\%), Amikacin (68.10\%), Gentamicin (56.86\%), Cotrimoxazole (35.13\%), Cefepime (24.42\%), Ciprofloxacin (24.28\%), Cefotaxime (17.71\%), Cefuroxime (14.68\%), Cefoxitin (13.0\%), Amoxycillin (8.20\%), and Ceftazidime (5.44\%). Over all sensitivity of $E$. coli was as follow - Imipenam (64.63\%), Amikacin (61.85\%), Gentamicin (52.75\%), Cotrimoxazole (37.90\%), Cefepime (27.03\%), Ciprofloxacin (26.62\%), Cefotaxime (21.50\%), Cefuroxime (12.20\%), Cefoxitin (12.50\%), Amoxicillin (10.54\%), and Ceftazidime (4.57\%).

The above study was conducted in a tertiary care hospital with a state of art facility of Clinical microbiology laboratory.

Our study shows over all antibiotic sensitivity of $E$. coli as well as antibiotic sensitivity of $E$. coli for different clinical specimens. Various clinical specimen shows difference in antibiotic sensitivity pattern. A study by Rugira Trojan et al., showed isolation rate of E. coli from pus specimen to be $51.2 \%$ while it is $36.14 \%$ in present study (Rugira Trojan, 2016).

A study by Adinortey et al., shows 100\% sensitivity to Imipenam for urine and other clinical specimen while it is ranging from $41.67 \%$ to $79.36 \%$ in present study. Same author has demonstrated susceptibility of amikacin ranging from $75.8 \%$ to $100 \%$ among various clinical samples while present study is having sensitivity of amikacin ranging from $35.2 \%$ to $81.9 \%$ (Adintory et al., 2017).

Many studies have shown higher resistance of E. coli towards Fluoroquinolone and cotrimoxazole (Lee et al., 2003; Arslan et al., 2005, Akram et al., 2007). In Asia some countries are not considering fluoroquinolone as a treatment of first line for recurrent cystitis (Lee et al., 2003; Gobernado et al., 2007).
Present study shows sensitivity of ciprofloxacin ranging from $4.76 \%$ to $41.67 \%$ and cotrimoxazole sensitivity from $20.63 \%$ to $58.33 \%$.

The isolation rate of $E$. coli from urine samples in study by Kibret et al., (2011) was $(45.5 \%)$. The present study and study by other researchers also have similar findings (Yismaw et al., 2010; Al-Tawfiq, 2006; Gangoué et al., 2004). In present study, the overall resistance of $E$. coli to antimicrobials was high.

The result is consistent with the findings of previous studies (Kibret et al., 2011; Orrett $e t$ al., 2001). In most of the clinical samples, $E$. coli showed high resistance rate of $>80 \%$ to amoxicillin.

The results of the present study are in line with the findings of other studies conducted in different parts of the world (Bharathi et al., 2008; Briscoe et al., 2005).

The resistance rates recorded in this study are higher than the results obtained by various other studies (Khan, 2002; Iqbal et al., 2002; Okonko et al., 2009; Zhanel et al., 2006; Karlowsky et al., 2002; Barrett et al., 2000; Iqbal et al., 2002; Kurutepe et al., 2005). This can be because of the duration of gap between present and previous studies.

The present study shows very high rate of resistance of $E$. coli isolated from various clinical specimens. E. coli should be treated promptly and effectively to prevent further increase in resistance.

Every hospital needs to prepare antibiogram not only according to organisms but also according to clinical specimens so that empirical therapy can be started before culture and sensitivity investigation (Table 1 and 2). 
Table.1 Shows number of $E$. coli isolated from different clinical specimens

\begin{tabular}{|c|c|c|}
\hline Specimen & $\begin{array}{c}\text { No of } \boldsymbol{E} \text {. coli } \\
\text { isolated }\end{array}$ & Percentage \\
\hline Urine & 627 & 50.69 \\
\hline Pus & 447 & 36.14 \\
\hline Sputum & 70 & 5.66 \\
\hline Blood & 43 & 3.48 \\
\hline $\begin{array}{c}\text { Endo Tracheal } \\
\text { Secretion }\end{array}$ & 15 & 1.21 \\
\hline Ascitic Fluid & 14 & 1.13 \\
\hline Pleural Fluid & 7 & 0.57 \\
\hline CSF & 6 & 0.48 \\
\hline Catheter Tip & 5 & 0.4 \\
\hline Peritoneal Fluid & 3 & 0.24 \\
\hline Total & 1237 & 100 \\
\hline
\end{tabular}

Table.2 Shows Percentage sensitivity of different antibiotics towards E. coli isolated from various clinical specimen.

\begin{tabular}{|c|c|c|c|c|c|c|c|c|c|c|c|}
\hline Antibiotic & \multirow{2}{*}{ 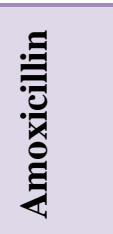 } & \multirow{2}{*}{ 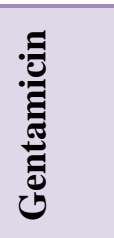 } & \multirow{2}{*}{ 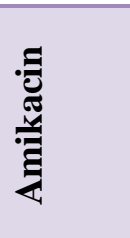 } & \multirow{2}{*}{ 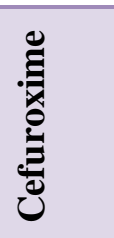 } & \multirow{2}{*}{ 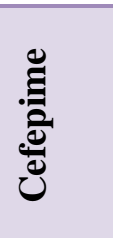 } & \multirow{2}{*}{ 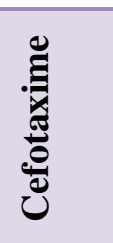 } & \multirow{2}{*}{ 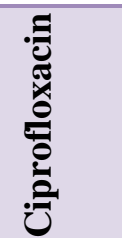 } & \multirow{2}{*}{ 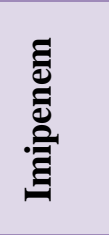 } & \multirow{2}{*}{ 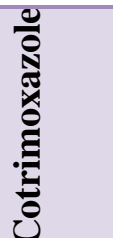 } & \multirow{2}{*}{ Ũ } & \multirow{2}{*}{ 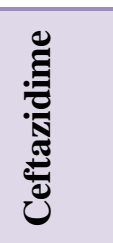 } \\
\hline Specimen & & & & & & & & & & & \\
\hline Urine & 8.20 & 56.86 & 68.10 & 14.68 & 24.42 & 17.71 & 24.28 & 77.90 & 35.13 & 13.00 & 5.44 \\
\hline Pus & 6.31 & 55.03 & 59.75 & 14.73 & 31.35 & 17.80 & 30.80 & 77.35 & 33.46 & 11.94 & 4.77 \\
\hline Sputum & 3.67 & 64.55 & 77.58 & 10.74 & 39.40 & 8.72 & 39.91 & 77.13 & 38.62 & 4.68 & 5.75 \\
\hline Blood & 17.44 & 61.22 & 76.45 & 13.95 & 28.90 & 10.08 & 40.84 & 74.10 & 28.27 & 10.30 & 0.00 \\
\hline $\begin{array}{c}\text { Endo } \\
\text { Tracheal } \\
\text { Secretion }\end{array}$ & 4.76 & 30.16 & 35.24 & 4.76 & 0.00 & 0.00 & 4.76 & 79.36 & 20.63 & 17.78 & 0.00 \\
\hline Ascitic Fluid & 6.67 & 55.48 & 81.90 & 4.76 & 30.95 & 35.71 & 13.09 & 60.48 & 50.71 & 13.09 & 4.76 \\
\hline $\begin{array}{c}\text { Pleural } \\
\text { Fluid }\end{array}$ & 0.00 & 66.67 & 61.11 & 16.67 & 11.11 & 16.67 & 16.67 & 50.00 & 22.22 & 0.00 & 0.00 \\
\hline CSF & 0.00 & 62.50 & 66.67 & 8.33 & 62.50 & 50.00 & 20.83 & 58.33 & 58.33 & 4.17 & 0.00 \\
\hline Catheter Tip & 41.67 & 41.67 & 41.67 & 0.00 & 8.33 & 41.67 & 41.67 & 41.67 & 41.67 & 33.33 & 8.33 \\
\hline $\begin{array}{c}\text { Peritoneal } \\
\text { Fluid }\end{array}$ & 16.67 & 33.33 & 50.00 & 33.33 & 33.33 & 16.67 & 33.33 & 50.00 & 50.00 & 16.67 & 16.67 \\
\hline Total & 10.54 & 52.75 & 61.85 & 12.20 & 27.03 & 21.50 & 26.62 & 64.63 & 37.90 & 12.50 & 4.57 \\
\hline
\end{tabular}

\section{References}

J. A. Berkley, B. S. Lowe, I. Mwangi et al.,
"Bacteremia among children admitted to a rural hospital in Kenya," The New England Journal of Medicine, vol. 352, 
no. 1, pp. 39-47, 2005.

H. Wang, M. Chen, Y. Ni et al., "Antimicrobial resistance among clinical isolates from the Chinese Meropenem Surveillance Study (CMSS), 2003-2008," International Journal of Antimicrobial Agents, vol. 35, no. 3, pp. 227-234, 2010.

Wagenlehner FM, Naber KG, Weidner W. Rational antibiotic therapy of urinary tract infections. Med Monatsschr Pharm. 2008; 31:385-90.

De Francesco MA, Giuseppe R, Laura P, Riccardo, N, Nin $M$. Urinary tract infections in Brescia, Italy: Etiology of uropathogens and antimicrobial resistance of common Uropathogens Med Sci Moni. 2007; 13(6): 136-144.

Kashef N, Djavid GE, Shahbazi S. Antimicrobial susceptibility patterns of community-acquired uropathogens in Tehran, Iran. J Infect Dev Ctries. 2010; 4(4): 202-206.

Biedenbach DJ, Moet GJ, Jones RN. Occurrence and antimicrobial resistance pattern comparisons among bloodstream infection isolates from the SENTRY Antimicrobial Surveillance Program (1997-2002). Diagn Microbiol Infect Dis. 2004; 50:59-69.

Gebre-Sellassie S.. Antimicrobial resistance patterns of clinical bacterial isolates in southern Ethiopia. Ethiop Med J. 2007; 45(4): 363-370.

Khan NA, Saba N, Abdus S, Ali AQ. Incidence and antibiogram patterns of E. coli isolates from various clinical samples from patients at $\mathrm{NIH}$ Islamabad. Pak J Biol Sci. 2002; (1):111-113.

Turner SM, Scott-Tucker A, Cooper LM, Henderson IR. Weapons of mass destruction: virulence factors of the global killer enterotoxigenic Escherichia coli. FEMS Microbial Letters. 2006; 263(1): 10-20.
Bell JM, Turnidge JD, Gales AC, Pfaller M. Jones RN, Sentry APAC Study Group. Prevalence of extended spectrum betalactamase (ESBL)- producing clinical isolates in the Asia-Pacific region and South Africa: regional results from SENTRY Antimicrobial Surveillance Program (1998-99). Diagn Microbiol Infect Dis. 2002; 42: 193-198.

El Kholy A, Baseem H, Hall G, Procop GW, Longworth DL. Antimicrobial resistance in Cairo, Egypt 1999-2000: a survey of five hospitals. $\mathrm{J}$ Antimicrob Chemother. 2003; 51: 625-630.

Dromigny JA, Nabeth P, Juergens-Behr A, Perrier-Gros-Claude JD. Risk factors for antibiotic resistant Escherichia coli isolated from community acquired urinary tract infections in Dakar, Senegal. J Antimicrobial Chemother. 2005.

Erb A, Stürmer T, Marre,R BrennerH. Prevalence of antibiotic resistance in Escherichia coli: overview of geographical, temporal, and methodological variations. Eur J Clin Microbial Infect Dis. 2007; 26: 83-90.

Cheesbourgh M. Medical laboratory manual for tropical countries. 2nd edition: England: Butterworth-Heineman LTD, 1991; 114-6.

Bauer, A.W., Kirby, W.M.M., Sherris, J.C. and Turck, M. Antibiotic susceptibility testing by standard single disc method. Am J. Clin Pathol 1996; 45: 493-496.

CLSI. Performance Standards for antimicrobial susceptibility testing; $27^{\text {th }}$ edition. CLSI supplement M100. Clinical and laboratory standard institute, 950 west valley road, suite 2500, Wayne, Pennsylvania 19087 USA, 2017.

CA Adintory, DHAK Amewowor, EPOtwe, IKA Gaiyuon and DKA Asante, 2017. Antibiotic susceptibility profile and 
occurrence of Escherichia coli isolated from clinical and environmental samples in Cape Coast, Ghana, Res. J. Microbiol, 12:170-176.

Lee SJ, Cho YH, Kim BW, Lee JG, Jung SI, Lee SD et al., A multicenter study of antimicrobial susceptibility of uropathogens causing acute uncomplicated cystitis in woman. Korean J Urol 2003; 44: 697-701.

Arslan H, Azap OK, Ergonul O, Timurkaynak F; Urinary Tract Infection Study Group. Risk factors for ciprofloxacin resistance among Escherichia coli strains isolated from communityacquired urinary tract infections in Turkey. J Antimicrob Chemother 2005; 56: 914-8.

Akram M, Shahid M, Khan AU. Etiology and antibiotic resistance patterns of community-acquired urinary tract infections in $\mathrm{J} \mathrm{N} M \mathrm{C}$ Hospital Aligarh, India. Ann Clin Microbiol Antimicrob 2007; 6: 4.

Gobernado M, Valdes L, Alos JI, Garcia-Rey C, Dal-Re R, Garcia-de-Lomas J. Spanish Surveillance Group for Urinary Pathogens. Antimicrobial susceptibility of clinical Escherichia coli isolates from uncomplicated cystitis in women over a 1-year period in Spain. Rev Esp Quimioter 2007; 20: 68-76.

Rugira Trojan,1 Lovely Razdan,2 and Nasib Singh3. Antibiotic Susceptibility Patterns of Bacterial Isolates from Pus Samples in a Tertiary Care Hospital of Punjab, India. International Journal of Microbiology Volume 2016, http://dx.doi.org/10.1155/2016/930269 2.

Kibret M, Abera B. Antimicrobial susceptibility patterns of $E$. coli from clinical sources in northeast Ethiopia African Health Sciences Vol 11 Special Issue 1 August 2011.
Yismaw G, Abay S, Asrat D, Yifru S, Kassu A Bacteriological profile and resistant patterns of clinical isolates from pediatric patients, Gondar University Teaching Hospital, Gondar Northwest Ethiopia. Ethiop. Med. J. 2010; 48(4): 293-300.

Al-Tawfiq JA. Increasing antibiotic resistance among isolates of Escherichia coli recovered from inpatients and outpatients in a Saudi Arabian Hospital. Infect Control Hosp Epidemiol 2006; 27: 748-753.

Gangoué JP, Koulla-Shirob S, Ngassama P, Adiogo D, Njine T, Ndumbe $P$. Antimicrobial resistance of Gramnegative bacilli isolates from inpatients and outpatients at Yaounde Central Hospital, Cameroon. Inter J Infect Dis. 2004; 8: 147-154.

Orrett FA, Shurl SM. Prevalence of resistance to antimicrobial of $E$. coli isolates from clinical sources at a private hospital in Trinidad. Jpn J Infect Dis. 2001; 54: 64-68.

Bharathi MJ, Ramakrishnan R, Maneksha V, Shivakuma C, Mittal S. Comparative bacteriology of acute and chronic dacryocystitis. Eye 2008; 22: 953-960.

Briscoe D, Rubowitz A, Assia EI. Changing bacterial isolates and antibiotic sensitivities of purulent dacryocystitis. Orbit 2005; 24: 95-98. 24.

Iqbal MK, Patel IK. Susceptibility patterns of Escherichia coli: Prevalence of multidrug-resistant isolates and extended spectrum beta-Lactamase phenotype. J Pak Med Asso. 2002; 52: 407-417.

Okonko IO. Soleye FA, Amusan TA, Ogun AA, Ogunnusi TA Ejembi J. Incidence of multi-drug resistance (MDR) organisms in Abeokuta, Southwestern Nigeria. Global J Pharm. 2009; 3(2): 69-80.

Zhanel, GG, Hisanaga TL, Laing NM, De 
Corby MR, Nichol KA, Weshnoweski et al., Antibiotic resistance in Escherichia coli outpatient urinary isolates: final results from the North American Urinary Tract Infection Collaborative Alliance (NAUTICA). Int J Antimicrob Agents. 2006; 27: 468-475.

Karlowsky JA, Kelly LJ, Thornsberry C, Jones ME Sahm DF. Trends in antimicrobial resistance among urinary tract infection isolates of Escherichia coli from female outpatients in the United States. Antimicrob Agents
Chemother. 2002; 6: 2540-2545.

Barrett SP, Savage MA, Rebec MP, Guyot A, Andrews N, Shrimpton SB. Antibiotic sensitivity of bacteria associated with community-acquired urinary tract infection in Britain. J Antimicrob Chemother. 2000; 44: 359-365.

Kurutepe S, Surucuoglue S, Sezgin C, Gazi H, Gulay M, Ozbakkaloglu B. Increasing antimicrobial resistance in E. coli isolates form community-acquired urinary tract infections during 1998 2003 in Minisa, Turkey. Jpn J Infect Dis. 2005; 58: 159-161.

\section{How to cite this article:}

Krunal Shah. 2019. A Comparative Study of Antibiotic Sensitivity Pattern of Escherichia coli Isolated from Various Clinical Samples over a Period of 3 Years. Int.J.Curr.Microbiol.App.Sci. 8(10): 1243-1249. doi: https://doi.org/10.20546/ijcmas.2019.810.146 